\title{
Characteristics of Clay Raw Materials from the Turów Lignite Mine Waste, Poland: Potential for Industrial Applications
}

\author{
Jan Kudełko *, Herbert Wirth, Wojciech Kaczan (D) and Lesław Bagiński
}

\author{
Department of Mining, Faculty of Geoengineering, Mining and Geology, Wrocław University of Science and \\ Technology, ul. Na Grobli 15, 50-421 Wrocław, Poland; herbert.wirth@pwr.edu.pl (H.W.); \\ wojciech.kaczan@pwr.edu.pl (W.K.); leslaw.baginski@pwr.edu.pl (L.B.) \\ * Correspondence: jan.kudelko@pwr.edu.pl
}

Citation: Kudełko, J.; Wirth, H.;

Kaczan, W.; Bagiński, L.

Characteristics of Clay Raw Materials from the Turów Lignite Mine Waste, Poland: Potential for Industrial Applications. Sustainability 2021, 13, 6513. https://doi.org/10.3390/ su13126513

Academic Editor: Antonio Zuorro

Received: 15 April 2021

Accepted: 2 June 2021

Published: 8 June 2021

Publisher's Note: MDPI stays neutral with regard to jurisdictional claims in published maps and institutional affiliations.

Copyright: (c) 2021 by the authors. Licensee MDPI, Basel, Switzerland. This article is an open access article distributed under the terms and conditions of the Creative Commons Attribution (CC BY) license (https:/ / creativecommons.org/licenses/by/ $4.0 /)$.

\begin{abstract}
Considering the diversity of clay raw materials, we can distinguish their numerous varieties using genesis and retention conditions, as well as specific physical, chemical, and thermal properties as criteria of division. Three samples of fine-grained clay materials, collected randomly from the Turów lignite mine tailing piles, were subjected to testing for their grain and chemical composition and specific surface area. The results show that the tested materials are non-porous adsorbents. Additionally, a thermal analysis was carried out with a simultaneous quadrupole mass spectrometry (QMS). In the tested samples, the weight loss associated with the release of water from the clay was observed in two temperature ranges: from 40 to $240{ }^{\circ} \mathrm{C}$ (physically bound water) and from 330 to $620^{\circ} \mathrm{C}$ (structured water). The weight loss associated with the decomposition of organic matter was registered in the temperature range of 300 to $560{ }^{\circ} \mathrm{C}$. The results of the conducted tests might provide the basis for further analysis of the potential use of these materials as heat stores, components of insulators, or additives of ceramic products.
\end{abstract}

Keywords: clay raw materials; waste; brown coal mining; circular economy

\section{Introduction}

Clay raw materials are common in the Earth's crust. Their specific properties related to the presence of certain chemical compounds, mineral and grain composition, as well as structural characteristics, render them suitable in a wide range of applications in numerous branches of the economy. Therefore, they remain the object of interest for scientists and researchers, who investigate the correlations between their basic characteristics and analyze their behavior in variable moisture and temperature conditions, and under the influence of mechanical factors $[1,2]$. The usefulness of clay raw materials is influenced by the grain size and the mineralogical composition of the finest fractions. Being diverse, clay raw materials exist in numerous varieties, which can be distinguished with the use of such criteria as their genesis, retention conditions, and specific physical and chemical properties.

The most typical varieties of clay raw materials are kaolin, bentonite, various types of loams, refractory and non-refractory shales, as well as loesses, fen soils, and silts. The above types of clay raw materials are found in the entire territory of Poland and some of them, being precious deposits, have become an area of interest for businesses [3].

The need for reducing waste generation and using it as a resource is one of the main aspects of the circular economy strategy and for future European politics [4]. Due to constantly growing consumption, research is needed on the possibilities of using waste, in particular those from mining $[5,6]$. This offers an opportunity for the sustainable production of goods while reducing the creation of new landfills. The goal of the circular economy is to create a strategy that will replace the former linear production while supporting enterprises and the environment. The implementation of new ideas for the management of accompanying raw materials should ultimately result in a positive economic effect for the producer [7-9]. 
This issue is particularly significant for the Turów mine in Poland (Figure 1) as the clays generated during stripping are largely non-selectively deposited. It was estimated that the use of Turoszów clays in the years 1951-2002 accounted for only $0.087 \%$ of their estimated resources and $0.049 \%$ of the volume of the removed overburden [10]. This situation is caused by the numerous quality parameters of Turoszów clays, which often disqualify them as utility raw materials. These include impurities with iron and titanium compounds, as well as quartz sand, siderite, and carbon inclusions [11].

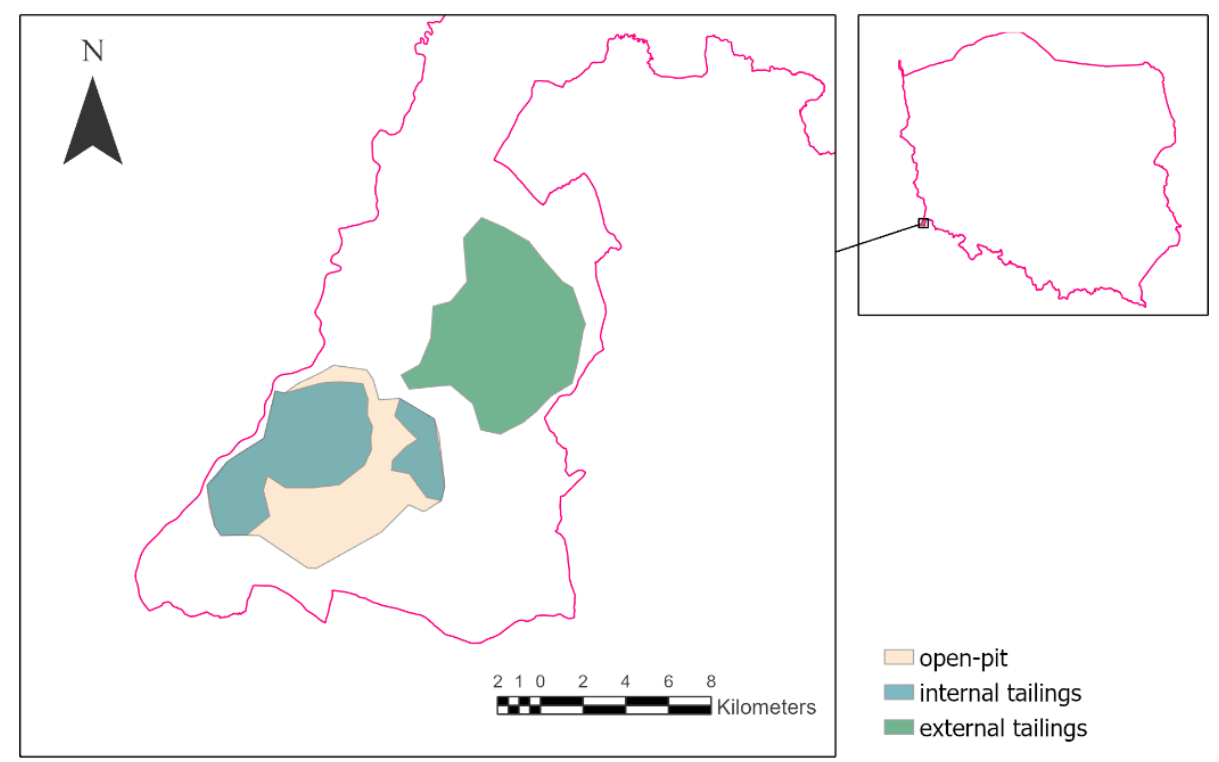

Figure 1. Study area: the Turów mine in south-western Poland (Dolnośląskie province).

Considering the growing need to change to a circular economy, the possibility of using clays from the production of the Turów mine, as well as those already deposited in tailings, should be analyzed. This article aims to present the results of research expanding the knowledge of Turoszów clays, with particular emphasis on the parameters related to their possible economic use.

\section{Materials and Methods}

\subsection{The Turoszów Clay Resource Base}

Some important information on the Turoszów clay resource base can be found in a study by Nieć [12]. However, its extent was estimated already in 1951, when the presence of clay was first confirmed. The deposit was documented as category D (Polish deposit classification). In the explored part of the lignite deposit, the documented resources comprised 15 million Mg of clays in the floor and 14.7 million Mg of clays in the roof. In 1960, refractory and ceramic clays were documented as accompanying mineral. Over 300 million $\mathrm{m}^{3}$ of minerals classified as balance resources were identified at that time [11].

\subsection{General Characteristics of the Deposit}

The Proterozoic crystalline basement is formed from magmatic-metamorphic rocks comprising plutonic rocks (also known as Rumburg granite), subvolcanic, volcanic, and metamorphic rocks [11]. Neogene sedimentary succession consists of coarse-grained crystalline, fine-grained clastic formations, and lignite (Figure 2). The profiles of Neogene sediments clearly show cyclical sedimentation. The lignite series formed by five sedimentation cycles with the gravel/sand-silt/clay-lignite succession. Each cycle began with medium-grained clastic rocks transforming upward into silt-clay rocks; the roof of the cycle consisted of a lignite bed or its sedimentary equivalent. Coarse-grained clastic sediments best-developed in the three lower cycles (coarse-grained gravels and sands). Phytogenic sediments form their coarsest beds in the roof of the second cycle, lignite bed I, and in the 
roof of the fourth cycle, lignite bed II. Siderite concretion levels are found across the entire sediments profile. In the upper part of the profile, above the lignite association, a complex of clastic sediments occurs, which has various fractions with small clay sediment intrusions. The Pleistocene sediments are mainly sands, sand-gravels, and South-Polish glacial period loams. Clastic deposits and fen soils from the Holocene occur mainly in river valleys.
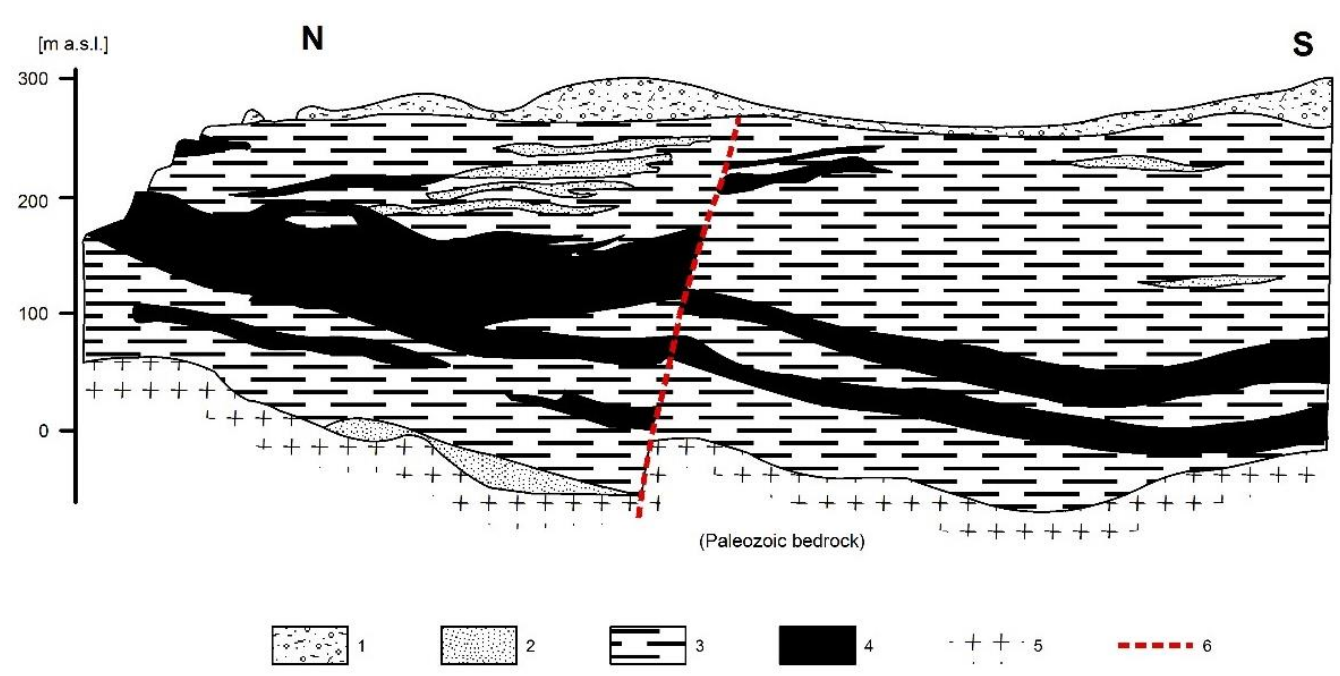

Figure 2. Schematic geological cross-section of Turów lignite deposit: 1—Quaternary, 2—sand, 3—clays, 4—coal, 5—granites, 6-fault (adapted from [10]).

Clay formations in the lignite series are found in three burden complexes. The first complex is above the upper lignite bed. It contains, directly below the humus layer, red-burned loams. They refer to the clay or loams formation, which by definition consist of approximately $40 \%$ sand, $40 \%$ silt, and $20 \%$ clay. They were extracted, to a limited extent, for construction ceramics production. Below the clays, the profile contains variously located, interpenetrating sand-gravel sediments, sand clays, lignite clays, and lignite layers.

The second complex is between lignite beds I and II. This comprises grey clay with various contents of sand, as well as sands and clay gravels. In some places, thin lignite interbedding and inclusions are also found.

The third complex is below the lower lignite bed I. This includes clay-sand sediments with partial lignite content located on granitoid and basalt rock detritus.

Cycles I and II form a below-lignite series (complex third-cycle I together with detritus of igneous rocks, granites, and basalts). Cycle III and IV correspond to the inter-lignite series, complex second, while cycle V corresponds to the above-lignite series, i.e., complex first.

The non-lignite complexes formed with varying content of sands in clay sediments. Changing sedimentation conditions resulted in the discontinuity of layers, lens-type clay formations, pocket intrusions of sand-gravel fractions, as well as siderite and pyrite intrusions in clays.

Based on lithological and color differences, the following varieties of clays were identified [11]:

- $\quad$ light grey clean, approx. $8 \%$;

- $\quad$ light grey sandy, approx. $50 \%$;

- brown, lignite-rich, approx. $30 \%$;

- granitoid and basalt clay detritus, approx. $12 \%$.

The $8 \%$ content of clean clays, suggested based on long-term observations, seems to be highly overestimated. 


\subsection{Characteristics of the Tested Materials}

The tests included three samples of fine-grade materials: two clay samples and one gravel sample (Table 1). Before detailed analyses, each sample was divided into two grain classes: $20-63 \mu \mathrm{m}$ and $-20 \mu \mathrm{m}$. The classification was performed manually, with the use of laboratory screening sieves and the wet method. A total of six samples were obtained, which were subsequently tested for grain composition, chemical composition, and specific surface.

Table 1. Description of the tested samples.

\begin{tabular}{cc}
\hline Sample Symbol & Sample Description \\
\hline $\mathrm{S} / 20-63$ & dark orange, a mix of gravels in various grain sizes \\
$\mathrm{D} / 20-63$ & light yellow, compact, powdery clay \\
$\mathrm{Z} / 20-63$ & black with darker grains \\
$\mathrm{S} /-20$ & dark orange, fine gravel \\
$\mathrm{D} /-20$ & light yellow, compact, powdery clay \\
$\mathrm{Z} /-20$ & black with very fine darker grains \\
\hline
\end{tabular}

\section{Results and Discussion}

\subsection{Grain Composition Tests}

Grain composition was tested in the Chemical Engineering Unit of the Faculty of Chemistry, Wroclaw University of Science and Technology, whereas the chemical composition and specific surface tests of clay materials were performed at the Department of Analytical Chemistry, Institute of Non-Ferrous Metals in Gliwice.

The tests were performed on two samples: a clay sample (designated as sample D) and a contaminated clay sample (designated as $Z$ ). Prior to the tests, both samples were wet screened to exclude grains larger than $0.063 \mathrm{~mm}$. The laser diffraction method (laser granulometry) is an alternative to work-intensive and burdensome measurements based on the sedimentation method and the sieve method.

The grain size analysis was performed with the use of a Mastersizer 2000 particle size analyzer manufactured by Malvern Instruments Ltd. The instrument measures particle size with a non-invasive laser diffraction method in a large micrometric particle range $(0.01-2000 \mu \mathrm{m})$. This method is based on the physical phenomena of lightwave diffraction and interference. The measurement consists of lighting the grain particle with a collimated laser beam. Depending on the grain size, the light refracts on its surface under various angles. In contrast to the still commonly used grain size analysis methods (i.e., sieve and sedimentation methods), this method allows a considerably shorter measurement and test preparation time, as well as higher precision [13]. Laser diffraction is currently the standard method both in laboratory and industry tests of grain size distribution in nano and micro powders, suspended solids, emulsions, and aerosols [14].

The analysis results indicated that the two clay samples had very small particles (Table 2, Figure 3). The clay sample contaminated with lignite grains $(\mathrm{Z} /-63)$ had noticeably smaller particles. More than $93 \%$ of this sample consisted of grains below $20 \mu \mathrm{m}$, while the D/ -63 clay sample contained $77 \%$ of such grains.

Table 2. Particle size distribution of two clay samples, D/ -63 and Z/-63.

\begin{tabular}{ccc}
\hline \multirow{2}{*}{ Grain Size Class, $\mu \mathrm{m}$} & \multicolumn{2}{c}{ Grain Size Content, $\%$} \\
\cline { 2 - 3 } & Sample D/-63 & Sample Z/-63 \\
\hline $0-2$ & 7.6 & 8.3 \\
$2-4$ & 18.5 & 27.2 \\
$4-10$ & 31.1 & 40.8 \\
$10-20$ & 19.8 & 16.9 \\
$20-40$ & 14.9 & 5.5 \\
$40-70$ & 8.1 & 1.3 \\
\hline
\end{tabular}




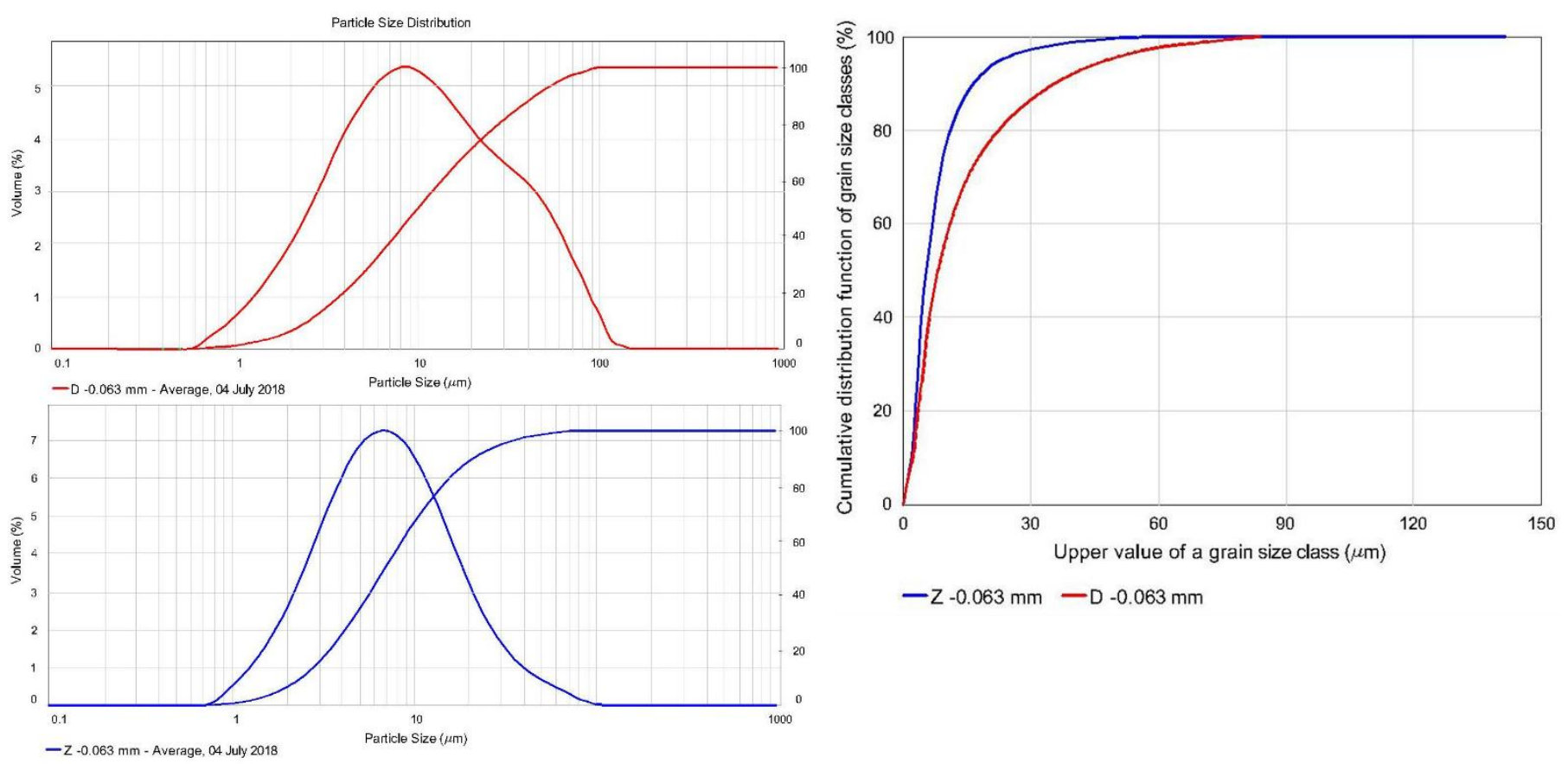

Figure 3. Particle size distribution curves of two clay samples.

\subsection{Chemical Composition Tests}

Chemical composition tests consisted of assaying the samples for aluminum, silicon, magnesium, manganese, potassium, sulfur, sodium titanium, calcium, and iron oxides, as well as for heavy metals: arsenic, zinc, nickel, lead, copper, and mercury. The implemented test methods were:

- $\quad$ Si content, with the gravimetric method;

- $\mathrm{Al}$ content, with the titrimetric method;

- $\quad \mathrm{Mg}, \mathrm{Mn}, \mathrm{K}, \mathrm{Na}, \mathrm{S}, \mathrm{Ti}, \mathrm{Ca}$, and Fe contents with Atomic Absorption Spectrometry (AAS);

- $\quad \mathrm{S}$ content, with the IR spectrometry method;

- $\quad \mathrm{Hg}$ content, with cold vapor atomic absorption spectrometry (CV AAS);

- $\mathrm{Pb}, \mathrm{Cu}, \mathrm{Zn}, \mathrm{Ni}$ content, with atomic absorption spectrometry (AAS),

- $\quad$ As content, with inductively coupled plasma mass spectrometry (ICP MS).

The tested samples were predominantly composed of $\mathrm{SiO}_{2}$ and $\mathrm{Al}_{2} \mathrm{O}_{3}$. However, a higher content of $\mathrm{Al}_{2} \mathrm{O}_{3}$ was observed for the samples with a finer fraction, $\mathrm{D} /-20$ and $\mathrm{Z} /-20$ (Table 3). The oxide composition of the tested fractions was diverse, for example, the $\mathrm{SiO}_{2}$ content for the +20 fraction ranged from $79.6 \%$ to $84.8 \%$, and for the -20 fraction, from $43.7 \%$ to $66.7 \%$. The analyses of metals showed non-significant amounts of heavy metals in the samples (Table 4). This type of material, containing appropriate chemical components and metals should be tested each time for specific requirements in terms of their use in animal breeding or improvement of agricultural land properties.

Table 3. Geochemical composition of bulk samples, wt. \%.

\begin{tabular}{ccccccccccc}
\hline $\begin{array}{l}\text { Sample } \\
\text { Symbol }\end{array}$ & $\mathbf{A l}_{\mathbf{2}} \mathbf{O}_{\mathbf{3}}$ & $\mathbf{S i O}_{\mathbf{2}}$ & $\mathbf{M g O}$ & $\mathbf{M n O}$ & $\mathbf{K}_{\mathbf{2}} \mathbf{O}$ & $\mathbf{S O}_{\mathbf{3}}$ & $\mathbf{N a}_{\mathbf{2}} \mathbf{O}$ & $\mathbf{T i O}_{\mathbf{2}}$ & $\mathbf{C a O}$ & $\mathbf{F e}_{\mathbf{2}} \mathbf{O}_{\mathbf{3}}$ \\
\hline $\mathrm{D} /-20$ & 36.30 & 43.76 & 0.320 & 0.011 & 1.20 & 0.085 & 0.150 & 3.77 & 0.320 & 2.23 \\
$\mathrm{D} /+20$ & 4.97 & 83.35 & 0.051 & 0.030 & 2.65 & 0.088 & 0.082 & 0.45 & 0.630 & 2.71 \\
$\mathrm{~S} /-20$ & 12.10 & 66.77 & 0.850 & 0.049 & 2.47 & 0.055 & 0.820 & 0.92 & 0.630 & 4.93 \\
$\mathrm{~S} /+20$ & 5.20 & 84.85 & 0.150 & 0.015 & 2.11 & 0.042 & 1.010 & 0.35 & 0.410 & 0.90 \\
$\mathrm{Z} /-20$ & 32.30 & 47.29 & 0.600 & 0.0057 & 3.15 & 0.093 & 0.240 & 1.20 & 0.076 & 1.70 \\
$\mathrm{Z} /+20$ & 6.39 & 79.61 & 0.093 & 0.0091 & 2.25 & 0.180 & 1.100 & 0.62 & 0.081 & 1.23 \\
\hline
\end{tabular}


Table 4. Bulk-sample heavy metal concentrations, ppm.

\begin{tabular}{ccccccc}
\hline $\begin{array}{l}\text { Sample } \\
\text { Symbol }\end{array}$ & As & Zn & Ni & Pb & Cu & Hg \\
\hline D/-20 & 4.1 & 450 & 96 & 32 & 59 & $<0.5$ \\
D/+20 & 1.4 & 62 & 10 & 16 & 24 & $<0.5$ \\
S/ -20 & 10.4 & 240 & 23 & 45 & 46 & $<0.5$ \\
S/+20 & 1.5 & 130 & $<10$ & 25 & 24 & $<0.5$ \\
Z/-20 & 6.8 & 120 & 29 & 49 & 24 & $<0.5$ \\
Z/+20 & 7.9 & 200 & 10 & 26 & 27 & $<0.5$ \\
\hline
\end{tabular}

\subsection{Determination of Specific Surface Area}

The specific surface was determined with a Gemini 2360 Micromeritics surface area analyzer. The method consists of measuring gas (nitrogen) adsorption on the surface of the adsorbate. The apparatus served to perform multipoint BET specific surface area measurements.

To remove impurities and moisture from the sample, it was dried for $2 \mathrm{~h}$ at a temperature of $110{ }^{\circ} \mathrm{C}$. The samples were degassed in the nitrogen protective atmosphere. The measurement was performed in the $\mathrm{P} / \mathrm{Po}$ range from 0.05 to 0.3 .

Approximate total specific surface in soils of various grain compositions are as follows:

- $\quad$ sand formations $7-15 \mathrm{~m}^{2} / \mathrm{g}$,

- loamy formations $14-24 \mathrm{~m}^{2} / \mathrm{g}$,

- dust formations $13-26 \mathrm{~m}^{2} / \mathrm{g}$, and

- clay formations $30-70 \mathrm{~m}^{2} / \mathrm{g}$.

Judging from the above results, the tested materials were classified as non-porous adsorbents. Porous adsorbents have specific surfaces from several hundred up to a thousand $\mathrm{m}^{2} / \mathrm{g}$. The increase in the specific surface is affected by the grain size, but even for the $-20 \mu \mathrm{m}$ grain size class for all samples, the surfaces were still very small (Table 5). By contrast, active carbon may have a specific surface of several hundred $\mathrm{m}^{2} / \mathrm{g}$.

Table 5. BET multipoint specific surface.

\begin{tabular}{ccc}
\hline Sample Symbol & Specific Surface, $\mathbf{~}^{2} / \mathbf{g}$ & Correlation Coefficient \\
\hline $\mathrm{D} /-20$ & $34.978 \pm 0.00770$ & 0.99960 \\
$\mathrm{D} /+20$ & $1.3823 \pm 0.0029$ & 0.99960 \\
$\mathrm{~S} /-20$ & $22.6025 \pm 0.0518$ & 0.99990 \\
$\mathrm{~S} /+20$ & $1.4148 \pm 0.0071$ & 0.99974 \\
$\mathrm{Z} /-20$ & $18.1183 \pm 0.0251$ & 0.99998 \\
$\mathrm{Z} /+20$ & $1.2865 \pm 0.0036$ & 0.99920 \\
\hline
\end{tabular}

\subsection{Thermal Analysis}

The analysis for the identification of thermal effects was performed at the Department of Analytical Chemistry, Institute of Non-Ferrous Metals in Gliwice (No. 0482d/2018). The test included an analysis of thermal effects and mass changes during the heating process according to the PBS-6-2 test procedure. The tests were performed at the Institute of Ceramics and Building Materials, Institute of Ceramics and Building Materials in Gliwice, Poland, with the use of a simultaneous thermal analyzer, STA 409 PC, manufactured by NETZSCH, coupled with a quadrupole mass spectrometer, QMS 403 Aeolos.

The tests also included an additional differential thermal analysis (DTA, red line), thermogravimetric (TG, green line) analysis, differential thermogravimetric analysis (DTG, blue line), released gas analysis $\mathrm{CO}_{2}$ (black line), and $\mathrm{H}_{2} \mathrm{O}$ (violet line). An approx. $35 \mathrm{mg}$ sample was placed in the crucible with $\mathrm{Al}_{2} \mathrm{O}_{3}$ and heated from a temperature of 40 to $900{ }^{\circ} \mathrm{C}$ at a rate of $10^{\circ} \mathrm{C} / \mathrm{min}$ with airflow of $30 \mathrm{~mL} / \mathrm{min}$. The conducted thermal analysis allowed us to determine the ranges of temperatures characteristic for such processes as dehydration and dehydroxylation of clay minerals (Figures 4-7). 


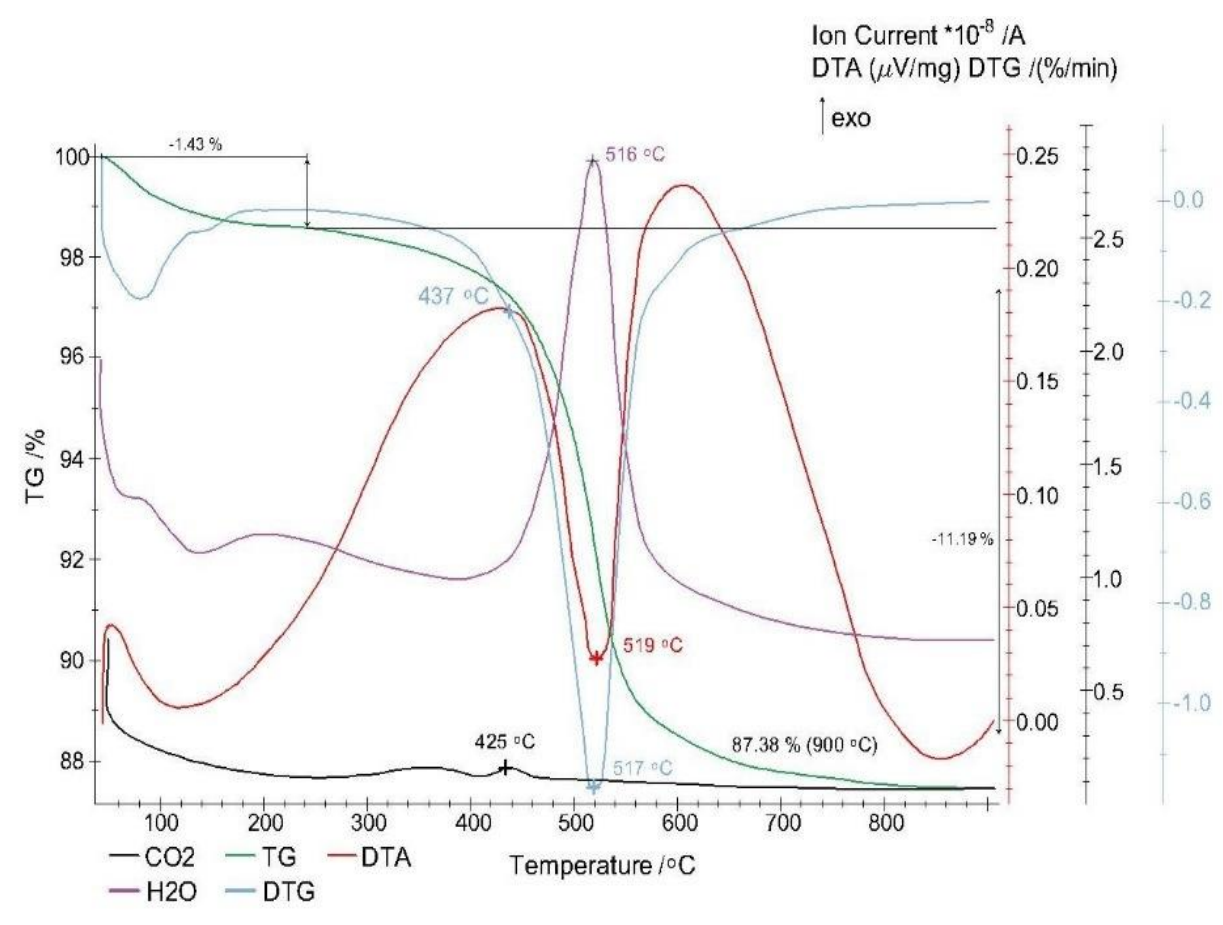

Figure 4. Thermal analysis results (sample D/ $-20 \mu \mathrm{m}$ ).

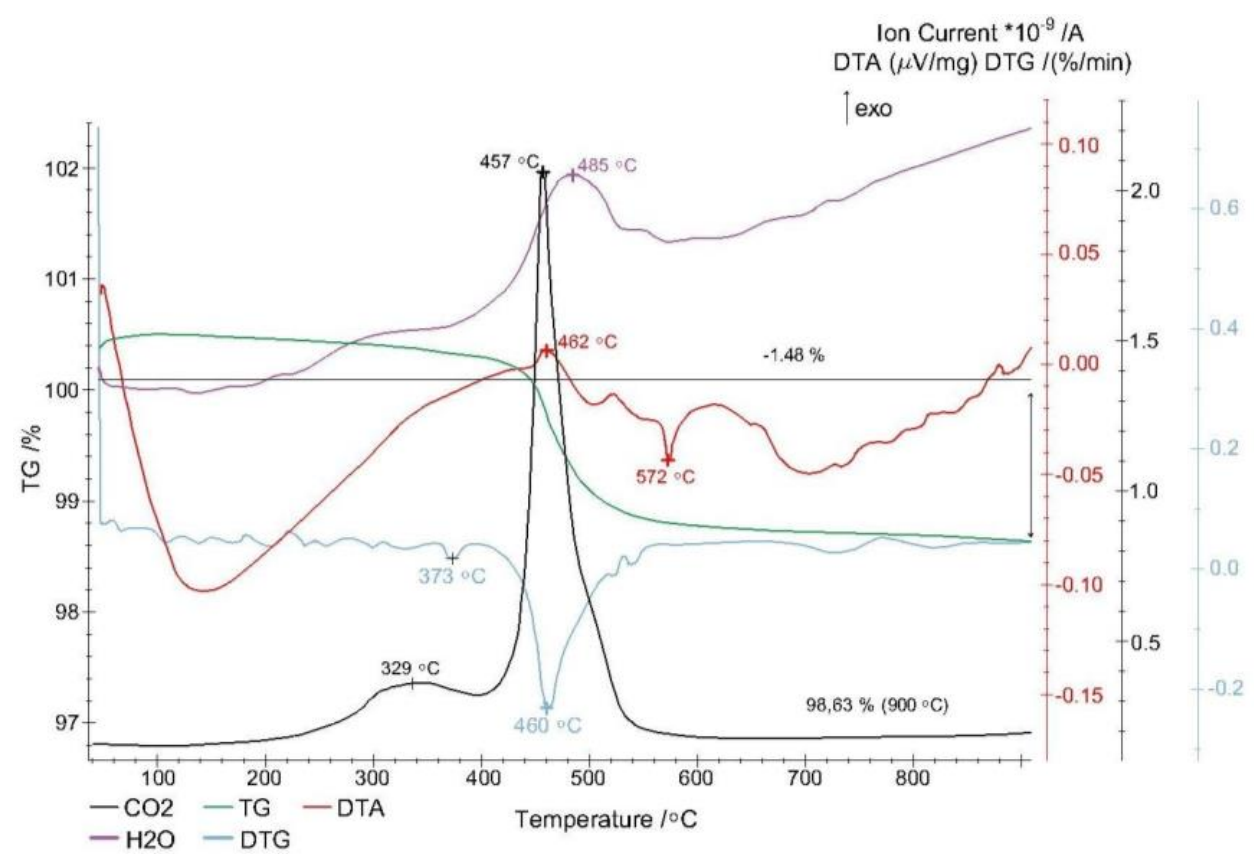

Figure 5. Thermal analysis result (sample D/ $+20 \mu \mathrm{m}$ ). 


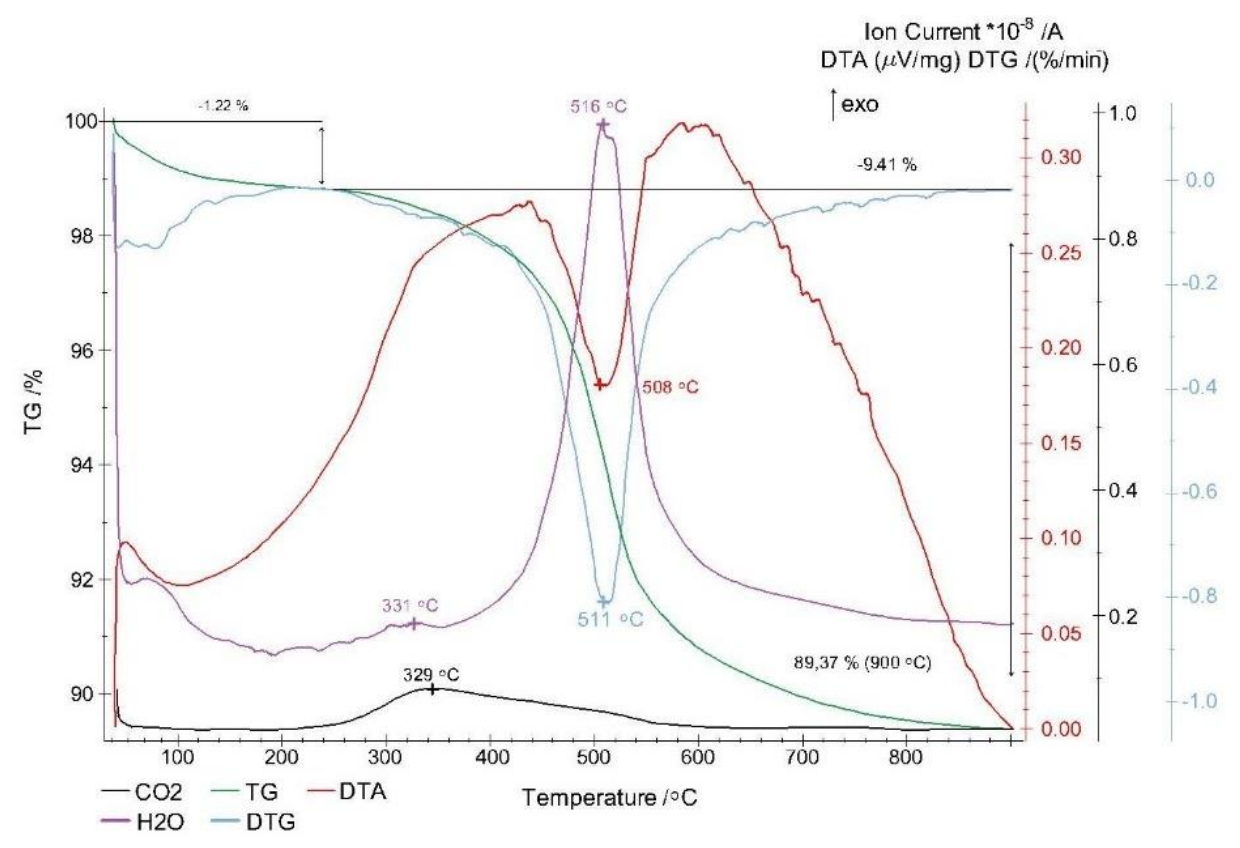

Figure 6. Thermal analysis result (sample $\mathrm{Z} /-20 \mu \mathrm{m}$ ).

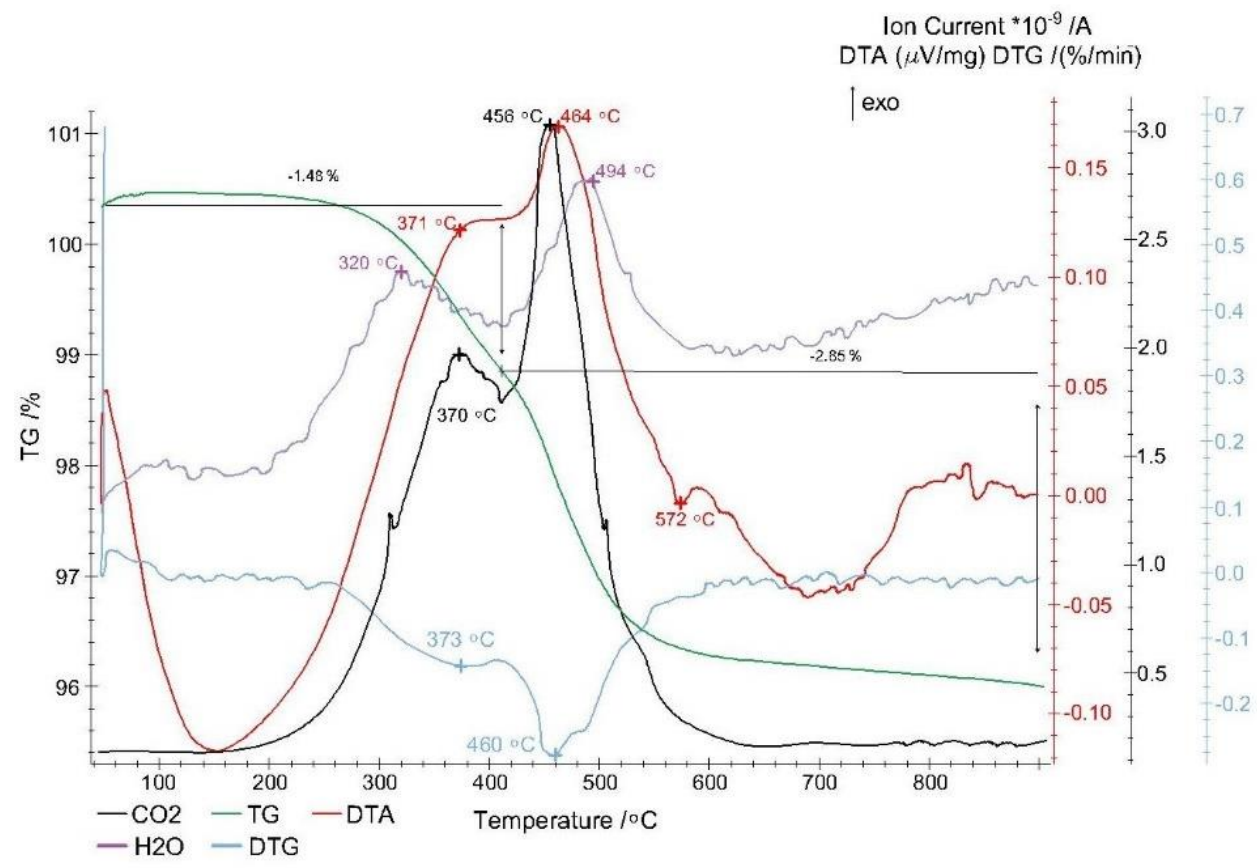

Figure 7. Thermal analysis result (sample Z/+20 $\mu \mathrm{m}$ ).

Thermal and sorption studies allowed us to determine the mineral composition of the samples as a mixture of kaolinite and illite. This interpretation is supported by the observations from other studies [15].

For sample D/ $-20 \mu \mathrm{m}$, the initial mass decrease of $1.43 \%$ is accounted for by the evaporation of chemically bound water (Figure 4). Another mass decrease of $11.19 \%$ is related to the separation of $\mathrm{CO}_{2}$ from the sample, with a maximum at $425^{\circ} \mathrm{C}$; the separation of $\mathrm{CO}_{2}$ corresponds to a minimum on the DTG curve at a temperature of $437^{\circ} \mathrm{C}$, and to the separation of $\mathrm{H}_{2} \mathrm{O}$ with a maximum at $517^{\circ} \mathrm{C}$, as well as to an endothermic effect with a minimum on the DTA curve at $519^{\circ} \mathrm{C}$.

The sample $\mathrm{D} /+20 \mu \mathrm{m}$ heated to $900{ }^{\circ} \mathrm{C}$ lost $1.48 \%$ of its original mass. At $329^{\circ} \mathrm{C}$, the first lower maximum of $\mathrm{CO}_{2}$ separated from the sample was observed (Figure 5). Some 
separation of $\mathrm{H}_{2} \mathrm{O}$ was also observed, albeit without a clear maximum in this temperature range; these effects correspond to a minimum on the DTG curve at $373{ }^{\circ} \mathrm{C}$. At $457{ }^{\circ} \mathrm{C}$, a second, much higher maximum of $\mathrm{CO}_{2}$ separation was observed, and at $485^{\circ} \mathrm{C}$, maximum of $\mathrm{H}_{2} \mathrm{O}$ separation was observed. The separation of these gases corresponds to a minimum on the DTG curve at $460{ }^{\circ} \mathrm{C}$. The separation of $\mathrm{CO}_{2}$ and $\mathrm{H}_{2} \mathrm{O}$ is related to the exothermic effect with a maximum on the DTA curve at $462{ }^{\circ} \mathrm{C}$. The exothermic effect may indicate an oxidation reaction in the sample. At $572{ }^{\circ} \mathrm{C}$, a considerable endothermic effect was observed, which can be related to the polymorphic transformation of quartz $\beta$ into quartz $\alpha$.

The first mass decrease in sample $Z /-20 \mu \mathrm{m}$ was $1.22 \%$ and is accounted for by the evaporation of chemically bound water (Figure 6). Another mass decrease of $9.41 \%$ is related to the separation of $\mathrm{H}_{2} \mathrm{O}$ and $\mathrm{CO}_{2}$. Low maxima were observed of $\mathrm{H}_{2} \mathrm{O}$ separation at $331{ }^{\circ} \mathrm{C}$ and $\mathrm{CO}_{2}$ separation at $343^{\circ} \mathrm{C}$. A second, much higher maximum of $\mathrm{H}_{2} \mathrm{O}$ separation at $516^{\circ} \mathrm{C}$ corresponds to a minimum on the DTG curve at $511{ }^{\circ} \mathrm{C}$ and to the endothermic effect with a minimum on the DTG curve at $508^{\circ} \mathrm{C}$.

For a sample $\mathrm{Z} /+20 \mu \mathrm{m}$, the mass decrease of $1.48 \%$ was caused by the separation of $\mathrm{H}_{2} \mathrm{O}$ with a maximum at $320^{\circ} \mathrm{C}$ and of $\mathrm{CO}_{2}$ with a maximum at $370{ }^{\circ} \mathrm{C}$ (Figure 7 ). The separation of these gases corresponds to a minimum on the DTG curve at $373{ }^{\circ} \mathrm{C}$ and to the exothermic effect with a maximum on the DTA curve at $371^{\circ} \mathrm{C}$. Another mass decrease of $2.85 \%$ is also related to the separation of $\mathrm{H}_{2} \mathrm{O}$ with a maximum at $494{ }^{\circ} \mathrm{C}$ and of $\mathrm{CO}_{2}$, with a maximum at $456{ }^{\circ} \mathrm{C}$. This decrease corresponds to a minimum on the DTG curve at $460{ }^{\circ} \mathrm{C}$. The DTA curve indicates an exothermic effect with a maximum at $464{ }^{\circ} \mathrm{C}$. Exothermic effects may indicate oxidation reactions in the sample. At $572{ }^{\circ} \mathrm{C}$, a rapid endothermic effect was observed, which can be related to the polymorphic transformation of quartz $\beta$ into quartz $\alpha$.

In the low-temperature range below $240{ }^{\circ} \mathrm{C}$, free, capillary and adsorbed water on the surfaces of clay particles is released. The weight loss of the sample was noticeable in the temperature range from 40 to $240{ }^{\circ} \mathrm{C}$. This effect corresponds to the endothermic peak on the DTA curve. The dihydroxylation process (the release of $\mathrm{OH}$ groups bound in the clay structure) is recorded on the thermal curve at the temperature from 330 to $620{ }^{\circ} \mathrm{C}$. The loss of mass corresponds to an endothermic effect on the DTA curve and a reflex on the mass spectrum of water. When interpreting the thermal curves, one should take into account the composition and degree of fragmentation of the rock, measurement time, and the amount of the test substance.

Thermal tests allow us to determine the ranges of temperatures characteristic for processes such as dehydration and dihydroxylation, combustion, and decomposition of carbonates of clay minerals of the studied rocks [16]. In the tested samples, the weight loss associated with the release of water from the clay was observed in two temperature ranges: from 40 to $240{ }^{\circ} \mathrm{C}$ (physically bound water) and from 330 to $620^{\circ} \mathrm{C}$ (structured water). On the other hand, it can be concluded that free water is released during the fragmentation of the sample to the appropriate fraction for the tests. Miocene rocks containing swelling clays are characterized by a high content of adsorbed water.

The effects related to the decomposition of organic matter are recorded in thermal curves. The DTA curve shows the first exothermic peak associated with water release. Most likely, this water comes from the decomposition of organic acids. Another exothermic effect is the evolution of $\mathrm{CO}_{2}$. The reaction initial and end temperatures, in this case, were in the range of $320-485^{\circ} \mathrm{C}$. For $+20 \mu \mathrm{m}$ samples at $572{ }^{\circ} \mathrm{C}$, a rapid endothermic effect was observed (DTA curve), which can be related to the polymorphic transformation of $\beta$ quartz into $\alpha$ quartz.

The total weight loss related to the clays (the sum of adsorbed and structural water) for the tested materials was in the range $1.2 \%$ to $12.6 \%$. The weight loss resulting from the lower temperature range $\left(40-240^{\circ} \mathrm{C}\right)$ was interpreted as originating entirely from water associated with clay minerals. The weight loss associated with the decomposition of organic matter was registered in the temperature range of 300 to $560{ }^{\circ} \mathrm{C}$. 


\section{Conclusions}

The quality research performed on the samples of clay accompanying the lignite from Turów mine allowed for the preliminary assessment of their suitability for geotechnical purposes related to the construction of mineral waterproofing screens. The comparison of the requirements is contained in the technical recommendations for the geoengineering facility. The fractions below $0.002 \mathrm{~mm}$ show the best properties for the construction of waterproofing screens [17]. According to us, this type of waste should be time-tested for specific requirements in terms of their use in animal breeding, environmental protection (waste disposal, immobilization of heavy metal), improvement in agricultural land properties, sanitation of contaminated sites, or construction of mineral screens $[18,19]$.

Thermal and sorption studies allowed us to determine the mineral composition of the wastes as a mixture of kaolinite and illite. This type of mixture can be used as a sorbent in pig farming and liquid manure disposal. An important element of utilization is the coagulation of ammonia anions contained in the slurry, which will be detailed in studies of ion exchangeability. The studies carried out on the basis of the obtained results indicate their potential use as feed additives. The mixture of tested raw materials shows good properties for the rehabilitation of degraded lands [20-24].

Porous adsorbents have specific surfaces from several hundred up to thousand $\mathrm{m}^{2 /} \mathrm{g}$. However, the results showed that the tested materials are classified as non-porous adsorbents. Another significant finding of this study is the thermal changes during heating. These variations indicate the potential use of these formations as heat stores, components of insulation materials, or additives to ceramic products.

Author Contributions: Conceptualization, H.W. and J.K.; methodology, J.K. and H.W.; software, L.B.; validation, H.W., J.K. and W.K.; formal analysis, J.K. and H.W.; investigation, J.K.; resources, J.K. and H.W.; data curation, J.K.; writing—original draft preparation, W.K.; writing—review and editing, W.K., H.W. and J.K.; visualization, L.B. and W.K.; supervision, J.K. and H.W.; project administration, J.K.; funding acquisition, J.K. All authors have read and agreed to the published version of the manuscript.

Funding: This work was part of project No. 0401/0127/17, titled: Clay Raw Materials in Agriculture, carried out at the Mining Division, Faculty of Geoengineering, Mining and Geology, Wroclaw University of Science and Technology.

Institutional Review Board Statement: Not applicable.

Informed Consent Statement: Not applicable.

Data Availability Statement: All the results of the tests are included in the article.

Conflicts of Interest: The funders had no role in the design of the study; in the collection, analyses, or interpretation of data; in the writing of the manuscript, or in the decision to publish the results.

\section{References}

1. Konta, J. Clay and man: Clay raw materials in the service of man. Appl. Clay Sci. 1995, 10, 275-335. [CrossRef]

2. Bergaya, F.; Theng, B.K.G.; Lagaly, G. Handbook of Clay Science, 1st ed.; Elsevier: Amsterdam, The Netherlands, 2006.

3. Budkiewicz, M.; Tokarski, Z. Surowce ilaste w Polsce. Kwart. Geol. 1971, 15, 172-193.

4. European Association for Coal and Lignite. Annual Report 2019; European Association for Coal and Lignite: Brussels, Belgium, 2020.

5. Kudełko, J. Effectiveness of mineral waste management. Int. J. Min. Reclam. Environ. 2018, 32, 440-448. [CrossRef]

6. Kudełko, J.; Nitek, D. Using wastes from mining activity as a substitute for raw materials. Cuprum Ore Min. Sci. Tech. Mag. 2011, 3, 51-63.

7. European Commission. A New Circular Economy Action Plan for a cleaner and more competitive Europe. In Communication from the Commission to the European Parliament, the Council, the European Economic and Social Committee and the Committee of the Region; European Commission: Brussels, Belgium, 2020.

8. Kaczan, W.; Wirth, H. Preliminary Analysis of Szklary Deposit (SW Poland) in the Aspect of Critical Metals Occurrence with Respect to the Circular Economy. In Proceedings of the XIX Conference of Ph.D. Students and Young Scientists: Interdisciplinary Topics in Mining and Geology, Sosnówka, Poland, 29-31 May 2019.

9. Kaźmierczak, U.; Kudełko, J.; Bagiński, L.; Wirth, H. Gospodarka o obiegu zamkniętym odpadami pogórniczymi i przeróbczymiPrzegląd możliwych rozwiązań na podstawie literatury polskiej. In Gospodarka o Obiegu Zamkniętym w Polityce i Badaniach Naukowych; Scientific Editor: Dr Hab. Joanna Kulczycka, Prof. AGH; Wydawnictwo IGSMiE PAN: Krakow, Poland, 2019; pp. 151-164. 
10. Ratajczak, T.; Hycnar, E. Kopaliny Towarzyszace w Złożach Węgla Brunatnego, Geologiczno-Surowcowe Aspekty Zagospodarowania Kopalin Towarzyszacych; Wydawnictwo IGSMiE PAN: Kraków, Poland, 2017.

11. Kaczarewski, T.; Pędziwol, A.; Wiśniewski, J. Wykorzystanie iłów turoszowskich-Możliwości i oczekiwania. Węgiel Brunatny Biul. Inf. Prod. Węgla Brunatnego 2007, 60, 27-33.

12. Nieć, M.; Matl, K.; Wyrwicki, R.; Wiśniewski, J. Ity Turoszowskie-Mit Kopalin Towarzyszacych, Studia i Rozprawy; Wydawnictwo IGSMiE PAN: Kraków, Poland, 2004.

13. Bartmiński, P.; Krusińska, A.; Bieganowski, A.; Ryżak, M. Przygotowanie próbek glebowych do pomiaru składu granulometrycznego gleb metodą dyfrakcji laserowej. Rocz. Glebozn. 2011, 62, 9-15.

14. Krawczykowski, D. Zastosowanie dyfrakcyjnej analizy laserowej do kontroli uziarnienia produktów przeróbki rud metali. Inżynieria Miner. 2017, 18, 233-240.

15. Szpila, K.; Widaj, B. Iły kaolinitowe warstw międzywęlowych kopalni Turów. Przegląd Geologiczny 1978, 26, $228-232$.

16. Przelaskowska, A.; Klaja, J.; Kulinowski, P.; Gaweł, A. Zastosowanie metod analizy termicznej w badaniach skał silikoklastycznych o zróżnicowanym zaileniu. Naft. Gaz 2017, 73. [CrossRef]

17. Asani, A. Application of bentomats and loam barrier as impermeable wall in flood banks. Zesz. Nauk. Uniw. Zielonogórskiego 2007, 13, 21-30.

18. Majer, E.; Łuczak-Wilamowska, B.; Wysokiński, L.; Dragowski, A. Zasady Oceny Przydatności Gruntów Spoistych Polski do Budowy Mineralnych Barier Izolacyjnych; ITB: Warsaw, Poland, 2007; pp. 1-162.

19. Majer, E.; Wysokińki, L. Badania Gruntów i Kontrola Jakości Wykonanych z Nich Przesłon Izolacyjnych na Składowiskach Odpadów; ITB: Warsaw, Poland, 2005.

20. Sałaciński, R.; Gąsiński, A. Możliwości wykorzystania gospodarczego surowców ilastych z plioceńskich iłów z KWB BełchatówPole Szczerców. Górnictwo Odkryw. 2012, 53, 83-89.

21. Łuczycka, D. Rolnictwo XXI Wieku: Problemy i Wyzwania 2018; Idea Knowledge Future: Wrocław, Poland, 2018; ISBN 978-83945311-9-5.

22. Regulation (EC) No 1831/2003 of the European Parliament and of the Council of 22 September 2003 on Additives for Use in Animal Nutrition. Available online: https:/ / ec.europa.eu/jrc/sites/jrcsh/files/EC-1831-2003.pdf (accessed on 7 June 2021).

23. Kłapyta, Z.; Żabiński, W. Sorbenty Mineralne Polski; AGH: Kraków, Poland, 2008; ISBN 978-83-7464-107-4.

24. Choma, J.; Zdenkowski, A.J. Strukturalne i powierzchniowe właściwości wybranych adsorbentów mineralnych. Ochr. Sr. 2001, 4, 5-8. 